JKKP: Jurnal Kesejahteraan Keluarga dan Pendidikan

http://doi.org/10.21009/JKKP

DOI: doi.org/10.21009/JKKP.051.06

E-ISSN: $2597-4521$

\title{
PENGARUH KELEKATAN ORANGTUA TERHADAP STRESS COPING PADA MAHASISWA YANG MENYUSUN SKRIPSI DI PRODI RUMPUN IKK, UNJ
}

\author{
Sukmawati $^{1, a)}$, Tarma $^{1, b)}$, Uswatun Hasana ${ }^{1, c)}$ \\ a)Watisukma552@gmail.com, ${ }^{\text {b) tarmasae@gmail.com, }{ }^{c} \text { uswatun hasanah@uni.ac.id }}$ \\ ${ }^{1,2,3)}$ Pendidikan Vokasional Kesejahteraan Keluarga \\ Fakultas Teknik, Universitas Negeri Jakarta \\ Jl. Rawamangun Muka Jakarta Timur 13220
}

\begin{abstract}
Abstrak
Terdapat beragam masalah stres yang dapat menghampiri mahasiswa, diantaranya yaitu stres yang terjadi ketika mehasiswa sedang melakukan penyusunan skripsi. Kondisi stres tersebut harus dilengkapi dengan cara coping yaitu mengatasi atau menghadapi kesulitannya. Salah satu faktor yang mempengaruhi stress coping adalah kelekatan dari orangtua. Penelitian ini bertujuan untuk memperoleh gambaran tentang pengaruh kelekatan orangtua terhadap stress coping mahasiswa yang menyusun skripsi yang dilakukan di prodi Rumpun IKK, UNJ. Metode penelitian yang menggunakan metode kuantitatif asosiatif. Teknik pengambilan data menggunakan Propotionate Cluster Stratified Random Sampling dengan jumlah sampel 168 responden. Hasil pengujian hipotesis menggunakan uji-t dengan taraf signifikan 0,05. Uji analisis diperoleh $t_{\text {hitung }} 9,49>t_{\text {tabel }} 1,65$, hal ini menjelaskan bahwa hipotesis nol ditolak dan hipotesis alternatif diterima sehingga dapat ditarik kesimpulan terdapat pengaruh yang positif dan signifikan antara kelekatan orangtua dengan stress coping mahasiswa. Berdasarkan hasil pengujian koefisien determinasi diperoleh hasil sebesar $35,00 \%$ dapat disimpulkan bahwa variabel kelekatan orangtua memberikan sumbangan efektif terhadap stress coping mahasiswa menyusun skripsi.
\end{abstract}

Kata Kunci : Kelekatan Orangtua, Stress Coping Mahasiswa.

\section{The Effect of Parental Attachment on Coping Stress of College in Complete their Undergraduate Thesis in Family Welfare Vocational Science}

\begin{abstract}
There are various stress problems that can approach students, including the stress that occurs when college are doing undergraduate thesis preparation. Stress conditions must be equipped with coping means of overcoming or facing difficulties. One of the factors that influence stress coping is the attachment of the parent. The aim of this research was to describe the effect of parental attachment on coping stress of college in complete their undergraduate thesis. This research used associative-quantitative methods. This research used of propotionate cluster stratified random sampling of respondents was 168 people. The analysis test showed that $t_{\text {count }} 9,49>t_{\text {tabel }} 1,65$ which means there is a significant correlation between the variable of parental attachment and coping stress of college in complete their undergraduate thesis. The cofficient of determination $35,00 \%$ showed that parental attachment on coping stress of college in complete their undergraduate thesis.
\end{abstract}




\section{PENDAHULUAN}

Terdapat beragam masalah stres yang dapat menghampiri mahasiswa, diantaranya yaitu stres yang terjadi ketika mahasiswa sedang melakukan penyusunan skripsi. Menurut Poerwadarminta (2003: 957) skripsi adalah karya ilmiah yang diwajibkan sebagai bagian dari persyaratan pendidikan akademis di Perguruan Tinggi. Skripsi bagi mahasiswa adalah suatu kewajiban yang harus diselesaikan dalam jangka waktu yang sesingkat mungkin, semakin cepat menyelesaikan skripsi dan di wisuda, semakin besar pula peluang untuk segera mencari pekerjaan. Namun, menyelesaikan sebuah skripsi tidaklah semudah mengerjakan makalah ataupun tugas-tugas mata kuliah pada umumnya, banyak kendala untuk mampu menyelesaikan skripsi, sehingga membuat mahasiswa merasa terbebani dan menjadi stres.

Adapun beberapa kesulitan yang dihadapi mahasiswa dalam melakukan penyusunan skripsi ini yaitu, banyaknya mahasiswa yang mengalami kesulitan dalam mencari bahan referensi atau teori yang terkait dengan penelitiannya, sulitnya bertemu dengan dosen pembimbing, sulitnya menyatukan atau menyamakan persepsi dan pendapat antara mahasiswa dan dosen pembimbing, rasa malas untuk mengerjakan skripsi, serta sulitnya membagi waktu antara skripsi dengan pekerjaan lainnya, sehingga hal ini dapat menimbulkan perasaan cemas, was-was, dan gelisah, dan menjadi stres.

Stres menjadi sangat sulit bahkan tidak dapat dihindari. Menurut Greenberg dalam Safaria (2009: 59) menyatakan bahwa ketika seseorang dihadapkan pada keadaan yang menimbulkan stres, maka individu itu terdorong untuk melakukan perilaku coping. Hal ini pun terjadi dengan mahasiswa, ketika mereka merasakan stres akibat dari menyusun skripsi, merekapun terdorong untuk melakukan perilaku coping. Ada banyak faktor yang ikut menentukan bagaimana stres bisa dikendalikan dan diatasi secara efektif, salah satunya adalah stress coping. Stress coping adalah strategi untuk mengelola tingkah laku kepada pemecahan masalah yang paling sederhana dan realistis, serta berfungsi untuk membebaskan diri dari masalah yang nyata maupun tidak nyata (Lazarus dalam Safaria, 2009: 97). Dan salah satu faktor yang mempengaruhi stress coping adalah kelekatan dari orangtua.

Kelekatan adalah ikatan paling awal yang terbentuk antara anak dan orangtua yang berdampak pada pembentukan hubungan yang berlanjut sepanjang hidup menurut Bowlby dalam Upton (2012: 82). Kelekatan orangtua sangat bermanfaat bagi anak untuk mendapatkan perlindungan, rasa aman, juga membantu anak untuk melakukan coping terhadap kejadian penyebab stres. Dalam membentuk kesejahteraan emosional seorang anak yang baik tergantung pada kualitas kelekatan antara anak dan orangtuanya. Anak yang dibesarkan dengan pola asuh yang peka dari orangtuanya terhadap sinyal-sinyal anak secara konsisten dapat membentuk pola komunikasi yang baik dan konsisten pula (Santrock, 2011: 312).

Berdasarkan hal ini, maka penulis mengemukakan gagasan bahwa, secara logika antara kelekatan orangtua sangat membantu anak untuk memilih strategi pemecahan masalah yang baik untuk mengurangi stresnya. Remaja harus menjaga kelekatan dengan keluarga khususnya ibu untuk menumbuhkan rasa kepercayaan yang tinggi untuk mengeksplorasi lingkungan baru. Keterikatan yang kokoh dengan orangtua juga dapat menyangga remaja dari kecemasan dan perasaan-perasaan depresi sebagai akibat dari masa transisi dari masa anak-anak ke masa remaja (Desmita, 2013: 219). Dengan demikian kelekatan pada anak yang dibentuk sejak kecil hingga menuju remaja akan menjadi pondasi anak dalam melewati masa-masa pengenalan lingkungan baru dikemudian hari dan dapat mensituasikan keadaan emosionalnya dengan baik. 


\section{METODOLOGI PENELITIAN}

Metode yang akan digunakan pada penelitian ini adalah metode penelitian survey melalui pendekatan kuantitatif asosiatif, dan peneliti menggunakan alat ukur kuesioner untuk mendapatkan data sebagai hasil penelitian. Hal ini sesuai dengan pernyataan Sugiyono (2011:6) bahwa metode survey ialah metode yang digunakan untuk mendapatkan data dari tempat tertentu yang alamiah (bukan buatan), tetapi peneliti melakukan pengumpulan data dengan menyebarkan kuesioner. Penelitian dengan metode survey termasuk kedalam metode pendekatan kuantitatif.

Populasi dalam penelitian ini yaitu mahasiswa angkatan 2012-2013 yang berstatus masih aktif dan sedang melakukan penyusunan skripsi di Prodi Rumpun IKK, UNJ dengan jumlah 168 responden..

Teknik pengambilan sampel yang digunakan dalam penelitian ini adalah teknik Propotionate dan Cluster Stratified Random Sampling. Pengambilan sampel dengan teknik Cluster Random Sampling adalah teknik pengambilan sampel apabila objek yang diteliti sangat luas (Sugiyono, 2010: 65). Sedangkan teknik Propotioned Random Sampling adalah teknik sampling yang dilakukan apabila populasi mempunyai anggota/unsur yang tidak homogen dan berstrata secara proporsional (Sugiono, 2010: 64). Pernyataan setiap butir dalam kuesioner diukur dengan menggunakan skala Likert yaitu 1 sampai 4 poin untuk skor terendah yaitu 1 dan untuk skala tertinggi yaitu 4 .

Instrumen variabel kelekatan orangtua yang digunakan berpedoman pada Teori Desmita (2013) dengan menggunakan 3 dimensi yaitu kelekatan aman, kelekatan melawan, dan kelekatan menghindar yang memiliki 31 soal. Kemudian pada variabel stress coping berpedoman pada teori Safaria (2009) yang menggunakan 2 dimensi yaitu stress coping terfokus pada masalah dan stress coping terfokus pada emosi yang memiliki 42 soal.

\section{HASIL DAN PEMBAHASAN}

Hasil penelitian menunjukkan bahwa terdapat pengaruh yang sedang dan signifikan antara variabel kelekatan orangtua dengan stress coping mahasiswa. Angka koefisien korelasi product moment $r=0,593$ dengan nilai $t_{\text {hitung }}(9,49)>t_{\text {tabel }}(1,65)$. Semakin tinggi tingkat kelekatan orangtua maka semakin tinggi tingkat stress coping mahasiswa, begitupun sebaliknya. Peran keterikatan yang aman dengan orangtua terhadap perkembangan remaja dapat membantu kompetensi sosial dan kesejahteraan sosialnya, seperti tercermin dalam ciri-ciri: harga diri, penyesuaian emosional, dan kesehatan fisik. Misalnya, remaja yang memiliki hubungan yang nyaman dan harmonis dengan mewujudkan seringnya komunikasi dengan orangtua mereka, akan memiliki harga diri dan kesejahteraan emosional yang lebih baik (Desmita, 2013: 218).

Berdasarkan uji regresi, diperoleh dengan rumus persamaan sebagai berikut : $\bar{Y}=64,090+$ $0,627 \mathrm{X}$ dengan interpretasi sebesar 64,090 dan nilai koefisien regresi sebesar 0,627 , sehingga nilai parameter koefisien arah regresi positif. Artinya setiap kenaikan kelekatan orangtua terhadap stress coping sebesar 1 satuan dengan nilai konstanta 64,090 akan menaikan stress coping mahasiswa sebesar 0,627 . Pada uji keberartian regresi dihasilkan $F_{\text {hitung }}(90,16)>F_{\text {tabel }}(3,90)$ maka dapat disimpulkan bahwa model persamaan regresi adalah signifikan. Perhitungan linieritas diperoleh $F_{\text {hitung }}(1,21)<F_{\text {tabel }}(1,47)$. Sehingga persamaan tersebut dapat digunakan untuk memprediksi secara signifikan dan linier pengaruh kelekatan orangtua terhadap stress coping mahasiswa yang menyusun skripsi. Hipotesis yang ditemukan dalam penelitian ini adalah $\mathrm{Ha} \rho \neq$ 0 terdapat pengaruh yang sedang dan signifikan antara kelekatan orangtua terhadap stress coping mahasiswa yang menyusun skripsl. Koefisien determinasi kelekatan orangtua memberikan sumbangan efektif terhadap stress coping sebesar $35,00 \%$, sisanya dipengaruhi oleh faktor lain.

Hasil perhitungan variabel kelekatan orangtua yang memiliki rata-rata sebesar 89.83 dan terdapat 3 dimensi yaitu: (1) kelekatan aman, (2) kelekatan melawan, dan (3) kelekatan 
menghindar. Dan dimensi tertinggi diperoleh pada dimensi kelekatan aman. Dapat dilihat pada Gambar 1.

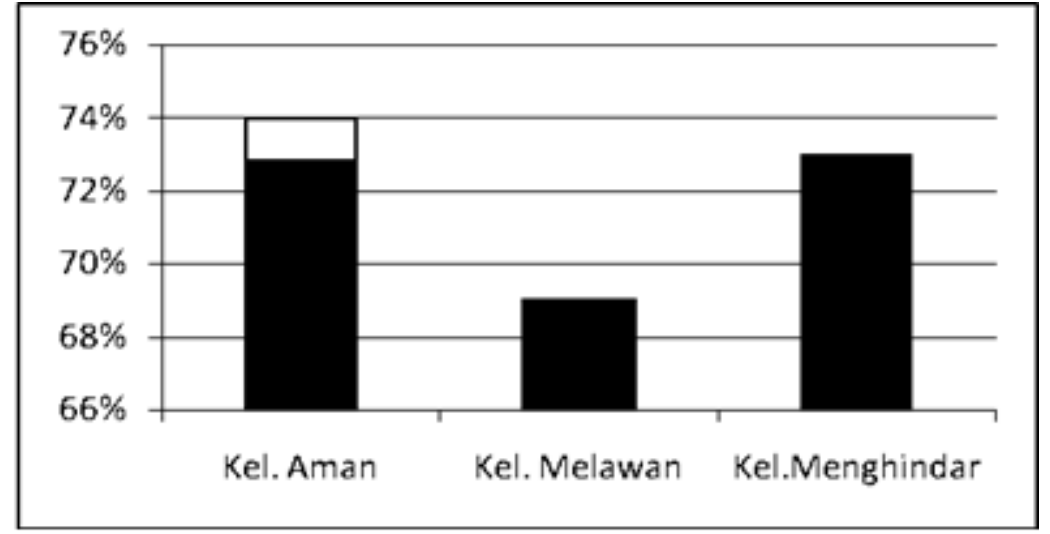

Gambar 1. Dimensi Variabel Kelekatan Orangtua

Gambar 1. Variabel kelekatan orangtua yang memiliki 3 dimensi, yang tertinggi diperoleh pada kelekatan aman dengan persentase sebesar $74 \%$, kelekatan melawan dengan persentase $69 \%$, dan kelekatan menghindar sebesar $73 \%$. Hal ini menunjukkan bahwa kelekatan aman sangat baik diterapkan pada anak di awal kehidupannya untuk keberlangsungan hidup anaknya dikemudian hari, karena dalam keterikatan yang aman dalam tahun pertama kehidupan bayi hingga berkembang ke masa dewasa ini memberi suatu landasan yang penting bagi perkembangan psikologis anaknya dikemudian hari (Desmita, 2013: 123). Keterikatan yang kokoh dengan orangtua dapat menyangga remaja dari kecemasan dan perasaan-perasaan depresi sebagai akibat dari masa transisi dari masa anak-anak ke masa remaja (Desmita, 2013: 219). Apabila keterikatan antara orangtua dan anak sudah kokoh maka terwujudnya kepercayaan pada anak yang dapat mendorong anak untuk membuktikan dirinya dapat dipercaya, karena seorang anak yang memiliki rasa percaya dalam dirinya cenderung untuk memiliki rasa aman dan percaya diri untuk mengeksplorasi Ingkungan baru.

Hasil perhitungan variabel stress coping memiliki hasil rata-rata 120,44. Pada variabel ini memiliki 2 dmensi yaitu: (1) stress coping terfokus pada emosi, dan (2) terfokus pada masalah. Dapat dilihat pada Gambar 2.

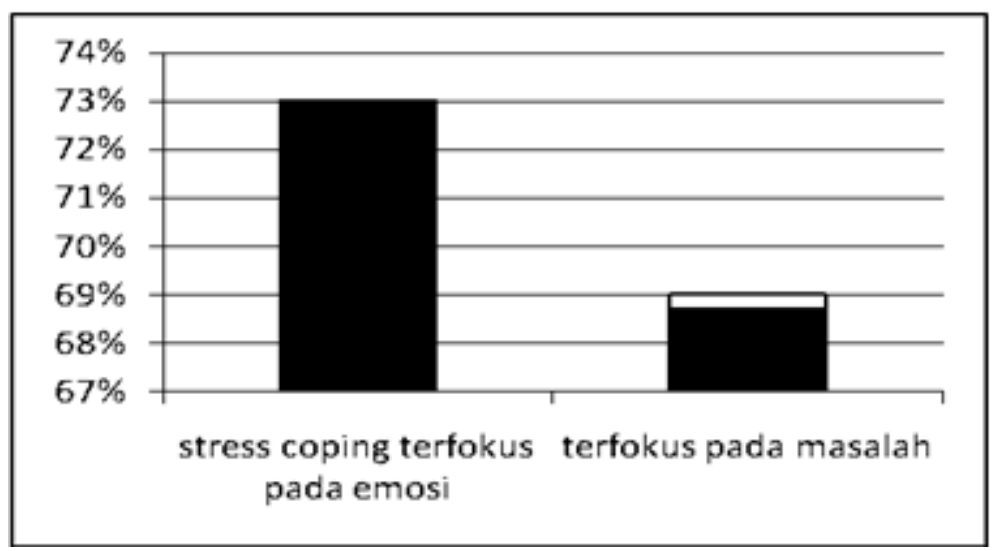

Gambar 2. Dimensi Variabel Stress Coping

Gambar 2. Variabel stress coping yang memiliki 2 dimensi, yang tertinggi diperoleh pada stress coping terfokus pada emosi dengan persentase sebesar $73 \%$. Hasil penelitian ini sejalan dengan pendapat Smet (1994) bahwa stress coping terfokus pada masalah sering digunakan oleh orang dewasa sedangkan remaja melakukan strategi pemecahan asalah yang terfokus pada emosi untuk mengatur respon terhadap stres. Jika individu tidak mampu mengubah situasi yang 
stresful tersebut maka ia cenderung untuk mengatur emosi yang timbul. Hal ini menunjukkan sebagian besar mahasiswa lebih menekankan pada usaha-usaha untuk menurunkan atau mengurangi emosi negatif yang dirasakan ketika menghadapi masalahnya. Dengan demikian, emosi positif dapat membantu individu untuk melihat gambar besarnya suatu masalah, merancang sebuah solusi, dan memungkinkan individu mendapatkan makna dari beragam pengalaman (King, 2010: 54).

\section{KESIMPULAN}

Berdasarkan deskripsi, analisis, interpensi data, pengolahan data statistik yang telah diuraikan pada bab sebelumnya, maka dapat disimpulkan sebagai berikut:

Hasil penelitian diketahui bahwa pengaruh kelekatan orangtua terhadap stress coping mahasiswa menyusun skripsi menunjukan hasil yang positif dengan kategori sedang. Pengaruh yang disumbangkan kelekatan orangtua terhadap stress coping mahasiswa sebesar $35,00 \%$, sedangkan sisanya $65,00 \%$ ditentukan oleh variabel lain yang tidak diteliti.

Kesimpulannya bahwa kelekatan orangtua berperan penting dalam pemilihan strategi pemecahan masalah anaknya ketika sedang dihadapkan pada suatu masalah. Semakin tingginya kelekatan orangtua yang diterapkan maka semakin tinggi stress coping pada anak.

Persentase dimensi tertinggi pada kelekatan orangtua yaitu kelekatan aman dengan persentase sebesar $74 \%$, yakni dengan kelekatan aman akan menumbuhkan rasa kepercayaan pada anaknya sehingga mempu untuk menghadapi lingkungan baru dan dapat mengelola emosinya dengan baik. Persentase terendah yaitu kelekatan melawan dengan persentase sebesar $69 \%$. Melihat hasil tersebut maka orangtua harus memberikan kasih sayang sepenuhnya keada anak sehingga anak tidak akan merasa cemas dan menuntut perhatian.

Persentase dimensi tertingi pada variabel stress coping yaitu stress coping terfokus pada emosi dengan persentase $73 \%$, yakni dengan strategi pemecahan masalah terfokus pada emosi lebih menekankan pada usaha-usaha untuk menurunkan atau mengurangi emosi negatif yang dirasakan ketika menghadapi masalahnya. Persentase terendah yaitu stress coping terfokus pada masalah dengan persentase sebesar $69 \%$. Melihat hasil tersebut remaja dalam menghadapi masalahnya harus mengimbangi antara mengatur masalahnya dan mengatur emosinya.

Oleh karena itu, orangtua memainkan peranan oenting dalam membantu anak khususnya untuk mengatur emosi anak, stress coping mahasiswa dipengaruhi oleh kelekatan antara orantua khususnya ibu karena strategi individual tidak cukup, perlu untuk mendapatkan bantuan dan dukungan orang lain yang berada dalam lingkungan keluarga.

\section{DAFTAR PUSTAKA}

Desmita. 2013. Psikologi Perkembangan. PT. Remaja Rosdakarya, Bandung.

King, Laura. A. 2010. Psikologi Umum. Buku 2. Salemba Humanika, Jakarta.

Poerwadarminta, W.J.S. 2003. Kamus Umum Bahasa Indonesia. PT.Balai Pustaka, Jakarta.

Safaria, T. 2009. Manajemen Emosi. PT. Bumi Aksara, Jakarta.

Santrock, W. J. 2011. Masa Perkembangan Anak. Edisi Kesebelas. Salemba Humanika, Jakarta

Smet, Bart. 1994. Psikologi Kesehatan. Grasindo, Jakarta.

Sugiyono. 2010. Metodologi Penelitian. Alfabeta, Jakarta.

Sugiyono. 2011. Metodologi Penelitian: Kualitatif, Kuantitatif dan R\&D. Alfabeta, Bandung.

Upton, P. 2012. Psikologi Perkembangan. Erlangga, Jakarta. 